\title{
Study and Comparison of Natural and Synthetic Chemical Compounds against Bacteria Strain
}

\author{
${ }^{a}$ Mokgadi Precious Mphahlele, ${ }^{\mathrm{b}}$ Dr Derek Ndinteh, Dr Djuidje Fotsing Marthe ${ }^{\mathrm{c}}$ and ${ }^{\mathrm{a}}$ Céline \\ Bonneaud
}

\begin{abstract}
The part of the chemistry in the pharmacologic fields is now well-established. However, new drugs need to appear every day due to the constant mutations and the appearance of novel resistances.

Bacterias are responsible for several diseases and can cause foodborn illness, urinary tract, gastrointestinal tract and respiratory tract infections, food poisoning, destructive changes to human lungs, nosocomial and wound infections. The aim of the study was to know if the selected synthetic and natural compounds show inhibitory activity against one or more bacteria strain. Different compounds were tested against 14 bacteria strains. A novel type of anti-bacterial compounds was discovered, which was found to be active against all the 14 tested bacteria strain. This activity was due to the presence of a triple bond associated with a ketone function.
\end{abstract}

Keywords-Bacteria strain, Antibiotics, Natural and Synthetic compounds.

\section{INTRODUCTION}

The part of the chemistry in the pharmacologic fields is now well-established. However, new drugs need to appear every day due to the constant mutations and the appearance of novel resistances. To face this issue, two possibilities have been developed: either researching molecules used by traditional medicine by extracting them from the plants, or doing a screening of synthetic compounds with the hope to find a better compound. This study discovered both facets against bacteria strain. The optimism of the early period of antimicrobial discovery has been tempered by the emergence of bacterial strains with resistance to these therapeutics ${ }^{1}$. Antimicrobial resistance (AMR) occurs when bacteria change and antibiotics fail. AMR is currently threatening the effective prevention of an increasing range of infections caused by bacteria that develop multiple antibiotic resistances. As antimicrobial usage increases, so does the level and complexity of the resistance mechanisms exhibited bacterial pathogens. Therefore, the struggle to gain the upper hand against infections continues to this day [2]-[3]. Due to this issue, the selection of natural and synthetic compounds is primordial. In this report, the natural compounds have been

Manuscript received October 20, 2017. This work was supported in part by the UJ Department of Applied Chemistry.

M. P Mphahlele is with Department of Applied Chemistry, University of Johannesburg, Doornfontein Campus, 2028, South Africa.

${ }^{b}$ Dr Derek Ndinteh is with ${ }^{b}$ Centre for Nanomaterials Science Research, University of Johannesburg, Doornfontein Campus, 2028, South Africa. extracted from the roots and the bark of Erythrina abyssinica, Erythrina Senegalensis and Millettia versicolor. These trees are from Africa and have been used for their different medicinal properties since a long time. Synthetic heterocycles are now very known for their wonderful properties in a lot of fields. For instance, nitrogen heterocycles are the building block of life. They are the key constituents of both DNA and RNA. Moreover, different nitrogen heterocycles are predominant functional groups in many coenzymes that mediate primary metabolic transformation [4]. Heterocycles containing endocyclic $\mathrm{N}$-hydroxy groups are also interesting for their bioactivity. In general, the nitrogen seems to give specific and remarkable properties even if it is situated outside the ring.

\section{II.MATERIAL AND METHODS}

\section{A. Material}

All reagents used were of analytical grade and unless otherwise mentioned, they were all purchased from Sigma Aldrich. The bacterial strains were obtained from Davies diagnostics.

Twelve bacterial strains (Gram-positive bacteria: Bacillus cereus (ATCC10876), B. subtilis (ATCC19659), Enterococcus faecalis (ATCC13047), Mycobacterium smegmatis (MC ${ }^{2} 155$, kind gift from the Centre of Excellence in Biomedical TB Research, University of the Witwatersrand), Staphylococcus epidermidis (ATCC14990) and S. aureus (ATCC25923). Gram-negative bacteria: Enterobacter cloacae (ATCC13047), Escherischia coli (ATCC25922), Klebsiella oxytoca (ATCC8724), K. pneumonia (ATCC13882), Proteus mirabilis (ATCC7002) and Pseudomonas aeruginosa (ATCC27853) were cultured overnight in Mueller-Hinton broth at $25{ }^{\circ} \mathrm{C}$; Merck Chemicals, SA). The turbidity of the culture solutions were adjusted to match a 0.5 McFarland standard within 15 minutes prior to antibacterial testing.

\section{B. Methods}

- Anti-bacterial tests of natural and synthetic compounds against bacteria strains:

Antibacterial studies were initiated by the disc diffusion method as a means to evaluate the most potent alkyl and aryl pyrimido[1,2-a]benzimidazole derivatives. In-vitro antibacterial screening was carried out using a filter-paper disc-agar diffusion procedure [22]. Sterile filter-paper blank discs $(6 \mathrm{~mm})$ were impregnated with $1 \mathrm{mg}$ of compounds. The 
disks were air-dried while Muller-Hinton agar plates (prepared earlier) were inoculated with the test bacteria using a sterile cotton swab. Impregnated filter-paper discs (loaded with the same masses of the test compounds) were then placed on the surface of agar plates to allow for the diffusion of the compounds into the agar, the plates were incubated at $37{ }^{\circ} \mathrm{C}$ for $16 \mathrm{hrs}$. Minimum inhibitory concentrations (MIC) of all the strains were determined by the broth microdilution assay [23]. The test compounds were accurately weighed and dissolved in DMSO to yield $512 \mu \mathrm{g} / \mathrm{ml}$. The dissolved compounds were then serially diluted in Mueller-Hinton broth till the lowest concentration of $1 \mu \mathrm{g} / \mathrm{ml}$. All dilutions were tested five-fold against each bacterial strain. $100 \mu \mathrm{l}$ of the bacterial suspension was mixed with $100 \mu$ l of pre-diluted test compound in a 96 microwell plate and left to incubate overnight at $37^{\circ} \mathrm{C}$. $10 \mu 1$ of a $0.02 \%(\mathrm{w} / \mathrm{v})$ tetrazolium sodium solution was added to each well and the plates were re-incubated for 2 hours. Visual change of the solution from blue to pink indicated that the bacteria were still alive. MIC was determined as the minimum concentration of compound

where no colour change could be observed. The MIC of all strains tested were compared to two reference antibiotics (nalidixic acid and streptomycin sulphate). This was due to the fact that whilst streptomycin is a broad based antibiotic, nalidixic acid has been shown to be exclusively active against Gram-negative bacteria [24].

- Minimal inhibitory concentration test:

Solutions of different concentrations $(8 \mathrm{mg} / \mathrm{mL}, 4 \mathrm{mg} / \mathrm{mL}$, $2 \mathrm{mg} / \mathrm{mL}, 1 \mathrm{mg} / \mathrm{mL}$ and $0.5 \mathrm{mg} / \mathrm{mL}$ ) were prepared using $\mathrm{N}, \mathrm{N}$ dimethylformamide as solvent. For each dilution, the experiment was repeated five times in 5 hells. In order to control, the sixth well contained MH Broth and activated bacteria. After incubating overnight, $10 \mu \mathrm{L}$ of indicator dye was added and after 2 hours, the results were visible.

- Minimal inhibitory concentration for antibiotics

The same tests was carried out for the two positive controls, which are primordial to check if the compound shows a better activity than the antibiotics.

\section{RESULTS \& DISCUSSION}

A. Anti-Bacterial Tests of Natural and Synthetic Compounds Against Bacteria Strains:

The results are reported on Annex 1

Two compounds; one synthetic and one natural; were found to be active. AFP 324 showed the best activity between all tested compounds. It had a better activity than the antibiotic especially for $\mathrm{Se}$, Ef, Ms and $\mathrm{Kp}$. It has also activity against $\mathrm{Be}, \mathrm{Ed}, \mathrm{Ecl}, \mathrm{Ko}, \mathrm{Pa}$ and Pm. The natural compound ZJW 050 showed an inhibition circle for Se, Ef, Ec, Kp, Pa, Ms and Be. Twelve compounds showed no activity for all bacteria strains (or except just one with a small inhibition disc): KAE 202, ZJW 032, TEE 4, TEE 3, ZTF 1016, AM ZTF 03, WH 13, TE 51, ZTF 02, ZTF 13 WH 22, AFP 341, AK ML8 and E122. No MIC tests were carried out for them. One bacteria strain had no good results for all tested compounds except the antibiotic: Proteus Vulgaris. With these results, several have been selected to do MIC tests in order to observe if the compound has a strong or a weak activity. This selection is linked with the quantity of the compounds.

\section{B. Minimal Inhibitory Concentration Test}

The results are reported on Annex 2

This was done to determine for which minimal concentration the compound is active. On the 27 compounds that were tested, only two compounds were efficient on several bacteria strains. The natural compound A2 showed excellent results with low minimal inhibition concentrations for 12 bacteria strains, which is the most active compound. The synthetic compound $\mathrm{C} 3$ also showed good results but the low quantity of product has prevented it to do all the possible tests. The concentrations under $0.5 \mathrm{mg} / \mathrm{mL}$ was determined for A2 compound. However, for all the compounds with a minimal inhibition concentration of less than $0.5 \mathrm{mg} / \mathrm{ml}$, suggest a very good activity with MIC in $\mu \mathrm{g} / \mathrm{mL}$.

\section{Minimal inhibitory concentration for antibiotics}

TABLE 1: MIC RESULTS FOR TWO ANTIBIOTICS (IN $\mu \mathrm{G} / \mathrm{ML}$ )

\begin{tabular}{|l|l|l|}
\hline Bacteria strain & Nalidixic acid & Streptomycin sulfate \\
\hline P. mirabilis & 32 & 128 \\
\hline P. vulgaris & 8 & 32 \\
\hline E. coli & $>512$ & 64 \\
\hline E. cloacae & 16 & $>512$ \\
\hline E. aerogenes & 256 & 16 \\
\hline E. faecalis & $>512$ & 128 \\
\hline K. ocytoca & 8 & 16 \\
\hline K. pneumonia & 64 & 64 \\
\hline B. cereus & 32 & 32 \\
\hline P. aeruginosa & $>512$ & 64 \\
\hline S. epidermitis & 64 & 8 \\
\hline S. aureus & 512 & 8 \\
\hline M. smegmatis & $>512$ & 64 \\
\hline B. subtilis & 16 & $<4$ \\
\hline With the resuls, & selected active compound have been \\
\hline
\end{tabular}

With these results, the selected active compounds have been gathered by similar structures to deduce relations between structures and biological activity.

D.Study of two sigmoidins (A and B): two natural compounds

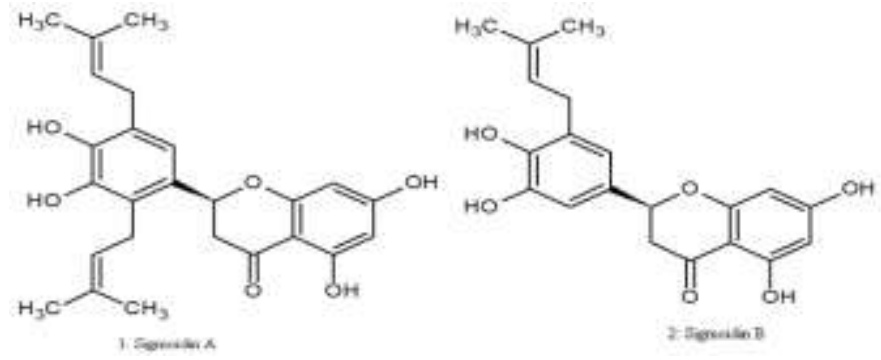

Fig 9: Structures of the sigmoidins A and B 
The inhibition of Staphylococcus Epidermitis has been

\begin{tabular}{|l|l|l|l|l|}
\hline Bacteria strains & $\begin{array}{l}\text { Sigmoidin } \\
\mathrm{B}\end{array}$ & $\begin{array}{l}\text { Sigmoidin } \\
\text { A }\end{array}$ & $\begin{array}{l}\text { Nalidixic } \\
\text { acid }\end{array}$ & $\begin{array}{l}\text { Streptonium } \\
\text { sulfate }\end{array}$ \\
\hline S.epidermitis & 500 & 31.25 & 64 & 8 \\
\hline S.aureus & 500 & $>500$ & 512 & 64 \\
\hline B. cereus & 500 & $>500$ & 32 & 32 \\
\hline E. faecalis & 500 & $>500$ & $>512$ & 128 \\
\hline K. ocytoca & 250 & $>500$ & 8 & 16 \\
\hline K. pneumonia & 500 & $>500$ & 64 & 64 \\
\hline B. subtilis & 250 & 250 & 16 & 16 \\
\hline M.smegmatis & 62.5 & 31.25 & $>512$ & $<4$ \\
\hline P. mirabilis & $>500$ & $>500$ & 32 & 128 \\
\hline P. vulgaris & 500 & $>500$ & 8 & 32 \\
\hline E. coli & 500 & $>500$ & $>512$ & 64 \\
\hline E. cloacae & 500 & $>500$ & 16 & $>512$ \\
\hline E. aerogenes & 500 & $>500$ & 256 & 16 \\
\hline P. aeruginos $a$ & 500 & $>500$ & $>512$ & 64 \\
\hline
\end{tabular}

observed with both sigmoidins using the disk diffusion method. But Sigmoidin B showed inhibitory activity against Sthapylococcus Aureus, Bacillus Cereus, Enterococcus faecalis and Mycobacterium Smegmatis and a weak activity against Escherichia Coli, Pseudomonas aeruginosa and Klebsiella pneumoni. And so the propyl group seems to increase the inhibitory activity. It could be deducted that
Sigmoidins showed a better activity against Gram-positive bacteria. It means that the antibiotics do not reach to cross the permeability barrier. However, Sigmoidin B can reach this barrier with a concentration around $500 \mathrm{mg} / \mathrm{mL}$.

\section{E. Study of the activity of pyrimido[1,2-a]benzimidazoles}

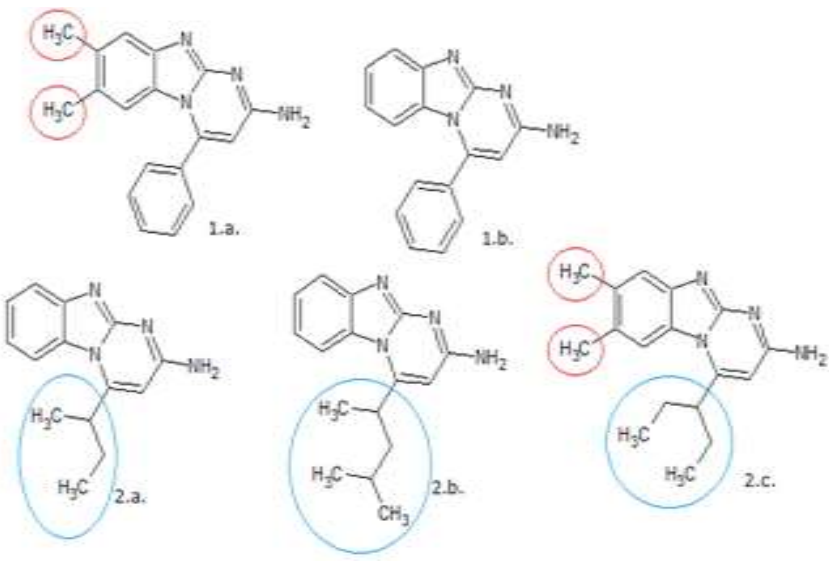

Fig 10: Structures of five pyrimido[1,2_a]benzimidazoles with different substituents

TABLE 3: MIC RESULTS FOR PYRIMIDO[1,2-A]BENZIMIDAZOLES

\begin{tabular}{|c|c|c|c|c|c|c|c|c|}
\hline \multirow[t]{2}{*}{ Bacteria Strain } & \multirow[t]{2}{*}{ 1.a. } & \multirow[t]{2}{*}{ 1.b. } & \multirow[t]{2}{*}{ 2.a. } & \multicolumn{2}{|l|}{ 2.c. } & \multirow[t]{2}{*}{ 2.b. } & \multirow{2}{*}{$\begin{array}{l}\text { Nalidixic acid } \\
\text { MIC }(\mu \mathrm{g} / \mathrm{mL})\end{array}$} & \multirow{2}{*}{$\begin{array}{l}\text { Streptonium sulfate } \\
\text { MIC }(\mu \mathrm{g} / \mathrm{mL})\end{array}$} \\
\hline & & & & Diameter(mm) & MIC & & & \\
\hline S. epidermis(+) & $\mathrm{R}$ & $\mathrm{R}$ & $\mathrm{R}$ & 22.8 & $15.62 \mu \mathrm{g} / \mathrm{mL}$ & $\mathrm{R}$ & 64 & 8 \\
\hline S. aureus $(+)$ & $\mathrm{R}$ & $\mathrm{R}$ & $\mathrm{R}$ & 21.5 & $31.25 \mu \mathrm{g} / \mathrm{mL}$ & $\mathrm{R}$ & 512 & 64 \\
\hline B. cereus $(+)$ & $\approx \mathrm{R}$ & $\mathrm{R}$ & $\mathrm{R}$ & 20.2 & $62.5 \mu \mathrm{g} / \mathrm{mL}$ & $\mathrm{R}$ & 32 & 32 \\
\hline B. $\operatorname{subtilis(+)}$ & $\mathrm{R}$ & $\mathrm{R}$ & $\mathrm{R}$ & 21.3 & $<3.90 \mu \mathrm{g} / \mathrm{mL}$ & $\mathrm{R}$ & 16 & 16 \\
\hline E. aerogenes(-) & $\mathrm{R}$ & $\mathrm{R}$ & $\mathrm{R}$ & 6.2 & $>500 \mu \mathrm{g} / \mathrm{mL}$ & $\mathrm{R}$ & 256 & 16 \\
\hline E. faecalis $(+)$ & $\approx \mathrm{R}$ & $\mathrm{R}$ & $\mathrm{R}$ & 21.0 & $62.5 \mu \mathrm{g} / \mathrm{mL}$ & $\mathrm{R}$ & $>512$ & 128 \\
\hline E. cloacae $(-)$ & $\mathrm{R}$ & $\mathrm{R}$ & $\mathrm{R}$ & 9.4 & $1 \mathrm{mg} / \mathrm{mL}$ & $\mathrm{R}$ & 16 & $>512$ \\
\hline E. $\operatorname{coli}(-)$ & $\mathrm{R}$ & $\mathrm{R}$ & $\mathrm{R}$ & 18.3 & $4 \mathrm{mg} / \mathrm{mL}$ & $\mathrm{R}$ & $>512$ & 64 \\
\hline P. mirabilis(-) & $\mathrm{R}$ & $\mathrm{R}$ & $\mathrm{R}$ & 13.5 & $2 \mathrm{mg} / \mathrm{mL}$ & $\mathrm{R}$ & 32 & 128 \\
\hline P. vulgaris(-) & $\mathrm{R}$ & $\mathrm{R}$ & $\mathrm{R}$ & $\mathrm{R}$ & - & $\mathrm{R}$ & 8 & 32 \\
\hline P. aeruginosa(-) & $\mathrm{R}$ & $\mathrm{R}$ & $\mathrm{R}$ & 11.5 & $2 \mathrm{mg} / \mathrm{mL}$ & $\mathrm{R}$ & $>512$ & 64 \\
\hline K.ocytoca(-) & $\mathrm{R}$ & $\mathrm{R}$ & $\mathrm{R}$ & 18.8 & $500 \mu \mathrm{g} / \mathrm{mL}$ & $\mathrm{R}$ & 8 & 16 \\
\hline K.pneumonia(-) & $\mathrm{R}$ & $\mathrm{R}$ & $\mathrm{R}$ & 18.8 & $62.50 \mu \mathrm{g} / \mathrm{mL}$ & $\mathrm{R}$ & 64 & 64 \\
\hline M. smegmatis(+) & $\mathrm{R}$ & $\mathrm{R}$ & $\mathrm{R}$ & 35.5 & $07.81 \mu \mathrm{g} / \mathrm{mL}$ & $\mathrm{R}$ & $>512$ & $<4$ \\
\hline
\end{tabular}

\section{$\mathbf{R}=$ Resistance}

The pyrimido[1,2-a]benzimidazoles can be substituted in different ways, therefore three positions have been tested (Figure 10) to know/check which substituent gives better activity. From these, 5 compounds were synthesized which were tested for antimicrobial activity and minimal inhibitory concentration (MIC). Compound 2C showed the best activity of all the 5 synthesized compounds. It also showed better activity than Nalidixic acid and Streptonium sulfate for Staphylococcus Aureus, Enterococcus Faecalis, Bacillus Subtilis and Klebsiella Pneumonia. This compound demonstrates an intermediate activity between the two antibiotics for Staphylococcus Epidermitis and Mycobacterium Smegmatis. It can be deduced that this compound is active against Gram-positive bacteria strain.

\section{F. Study of $\mathrm{N}$-(1H-benzimidazol-2-yl)oct-2-ynamides}

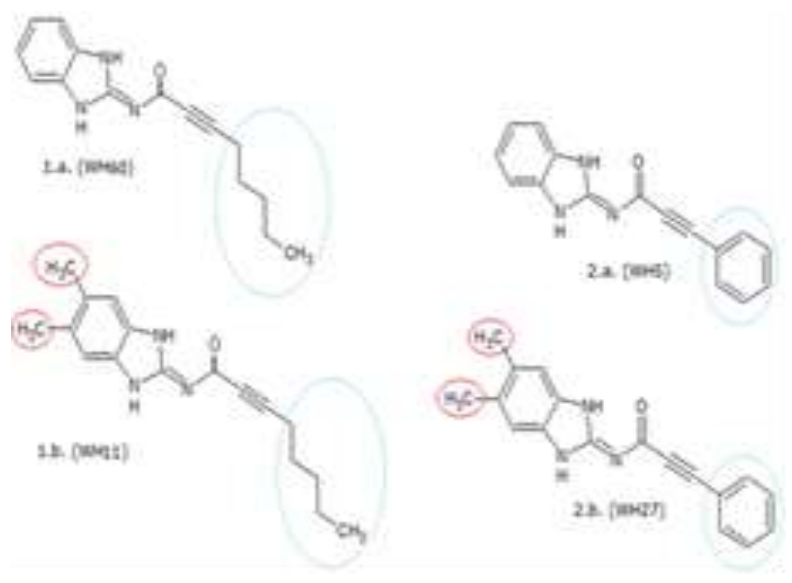

Fig 11: Structures of N-(1H-benzimidazol-2-yl)oct-2-ynamides

TABLE 4: MIC RESULTS FOR N-(1H-BENZIMIDAZOL-2-YL)OCT-2-YNAMIDES 
The dimethyled compound showed a better activity than the

\begin{tabular}{|l|l|l|l|l|l|}
\hline Bacteria strain & 1. a. & $1 . \mathrm{b}$. & $2 . \mathrm{a}$. & $2 . \mathrm{b}$. \\
\hline S.epidermitis & 500 & $>500$ & & 250 & 250 \\
\hline S.aureus & 250 & 250 & & 5050 & 250 \\
\hline B. cereus & 250 & 250 & & 500 & 500 \\
\hline E. faecalis & 250 & 250 & & $>500$ & 250 \\
\hline K. ocytoca & 250 & 250 & & 250 & 250 \\
\hline K. pneumonia & 500 & 250 & & 500 & 125 \\
\hline B. subtilis & 250 & 125 & $<3.9$ & 125 & 250 \\
\hline M.smegmatis & 125 & 250 & 125 & 125 & 62.5 \\
\hline P. mirabilis & 500 & 500 & & 500 & 500 \\
\hline P. vulgaris & 250 & 500 & & 500 & 250 \\
\hline E. coli & 250 & 250 & & 500 & 250 \\
\hline E. cloacae & 250 & 250 & & 250 & 250 \\
\hline E. aerogenes & 500 & 250 & & 500 & 500 \\
\hline P. aeruginosa & 250 & 250 & & 250 & 250 \\
\hline
\end{tabular}

non-methyled compound when it was tested by disk diffusion method. So the methyl groups seem to increase the inhibitory activity. Therefore, the dimethyled compound had a good activity against Gram-positive and Gram negative bacteria. It means that it can reach and cross the permeability barrier and the outer barrier. The dimethyled compound seem to be a very efficient compound. Moreover, the results of MIC indicate quite good results for all the compounds which means that the activity is given by the triple bond linked with ketone function. The dimethyled compounds seem to have a better activity even if it is to a lesser extent.

\section{G.Study of five last compound}

TABLE 5: MIC RESULTS FOR 5 COMPOUNDS

These

\begin{tabular}{|c|c|c|c|c|c|c|c|}
\hline Bacteria strains & $\begin{array}{l}1 \\
\text { WH } 30\end{array}$ & $\begin{array}{ll}2 \\
\text { ES } 121\end{array}$ & $\begin{array}{l}3 \\
\text { Dimethyl alpinium }\end{array}$ & $\begin{array}{l}4 \\
\text { SN } 82\end{array}$ & $\begin{array}{l}5 \\
\text { ZJW } 050\end{array}$ & Nalidixic acid & $\begin{array}{l}\text { Streptonium } \\
\text { sulfate }\end{array}$ \\
\hline S.epidermitis & $>500$ & $>500$ & $>500$ & $>500$ & 31.25 & 64 & 8 \\
\hline S.aureus & $>500$ & $>500$ & $>500$ & $>500$ & 125 & 512 & 64 \\
\hline B. cereus & $>500$ & $>500$ & $>500$ & $>500$ & 125 & 32 & 32 \\
\hline E. faecalis & $<3.9$ & $>500$ & $>500$ & $>500$ & 125 & $>512$ & 128 \\
\hline K. ocytoca & $>500$ & $>500$ & $>500$ & $>500$ & 62.5 & 8 & 16 \\
\hline K. pneumonia & $>500$ & $>500$ & $>500$ & $>500$ & 62.5 & 64 & 64 \\
\hline B. subtilis & 500 & 125 & $>500$ & 125 & $<1.95$ & 16 & 16 \\
\hline M.smegmatis & 7.81 & 125 & $>500$ & 62.5 & $<1.95$ & $>512$ & $<4$ \\
\hline P. mirabilis & $>500$ & $>500$ & $>500$ & $>500$ & $>500$ & 32 & 128 \\
\hline P. vulgaris & $>500$ & $>500$ & $>500$ & $>500$ & $>500$ & 8 & 32 \\
\hline E. coli & $>500$ & $>500$ & $>500$ & $>500$ & $>500$ & $>512$ & 64 \\
\hline E. cloacae & $>500$ & $>500$ & $>500$ & $>500$ & 125 & 16 & $>512$ \\
\hline E. aerogenes & $>500$ & $>500$ & $>500$ & $>500$ & $>500$ & 256 & 16 \\
\hline P. aeruginosa & $>500$ & $>500$ & $>500$ & $>500$ & $>500$ & $>512$ & 64 \\
\hline
\end{tabular}

compound compounds have been selected due to their imminent publication in order to see if they had a biological activity against 14 bacteria strain besides their normal use or their new discovered properties. The compound ZJW 050 represents the

C3 (part III. d. ii.) with impressive results especially against $B$. Subtilis and M.smegmatis.

\section{H.Synergetic effects between two compounds}

TABLE 6: MIC RESULTS OF SYNERGETIC EFFECTS BETWEEN A2 \& WH104

The active compound A2 showed excellent activities against concentration than the antibiotics against Staphylococcus

\begin{tabular}{|c|c|c|c|c|c|c|c|c|c|c|}
\hline Bacteria strain & $\begin{array}{l}\text { Pure } \\
\text { compound } \\
\text { A2 }\end{array}$ & $\begin{array}{l}\mathrm{A} 2+ \\
5 \mu \mathrm{L} \\
\mathrm{WH} 104\end{array}$ & $\begin{array}{l}\text { A2 + } \\
10 \mu \mathrm{L} \\
\text { WH104 }\end{array}$ & $\begin{array}{l}\text { A2+ } \\
20 \mu \mathrm{L} \\
\text { WH104 }\end{array}$ & $\begin{array}{l}\mathrm{A} 2+ \\
30 \mu \mathrm{L} \\
\mathrm{WH} 104\end{array}$ & $\begin{array}{l}\text { A2+ } \\
40 \mu \mathrm{L} \\
\text { WH104 }\end{array}$ & $\begin{array}{l}\mathrm{A} 2+ \\
50 \mu \mathrm{L} \\
\mathrm{WH} 104\end{array}$ & $\begin{array}{l}100 \mu \mathrm{L} \\
\text { WH104 }\end{array}$ & $\begin{array}{l}\text { Nalidixic } \\
\text { acid }\end{array}$ & $\begin{array}{l}\text { Streptonium } \\
\text { sulfate }\end{array}$ \\
\hline S.epidermitis & 15.63 & 15.25 & 14.89 & 14.21 & 6.79 & 6.51 & 6.25 & Pink & 64 & 8 \\
\hline S.aureus & 31.25 & 15.25 & 7.44 & 7.10 & $<3.40$ & $<3.26$ & $<3.12$ & Pink & 512 & 64 \\
\hline B. cereus & 62.5 & 60.98 & 29.76 & 28.41 & 27.17 & 26.04 & 25 & Pink & 32 & 32 \\
\hline E. faecalis & 62.5 & 15.24 & 14.88 & 14.20 & 15.59 & 13.02 & 12.5 & Pink & $>512$ & 128 \\
\hline K. ocytoca & 250 & 121.95 & 119.05 & 113.64 & 108.7 & 104.17 & 100 & $\approx$ Pink & 8 & 16 \\
\hline K. pneuтопiа & 62.5 & 30.49 & 29.76 & 28.41 & 27.17 & 26.04 & 25 & Pink & 64 & 64 \\
\hline B. subtilis & $<3.9$ & $<3.80$ & $<3.71$ & $<3.55$ & $<3.39$ & $<3.25$ & $<3.12$ & $\approx$ Blue & 16 & 16 \\
\hline M.smegmatis & 15.63 & 15.25 & 14.89 & 7.10 & 6.79 & $<3.25$ & $<3.12$ & $\approx$ Pink & $>512$ & $<4$ \\
\hline
\end{tabular}

bacteria strain. In addition to the excellent results, another interesting study was to bring to light the synergetic effects between two synthetic compounds, A2 and WH104. Although the compound A2 had good activity, the goal was to improve this activity obtaining lowest minimal inhibitory concentrations. The compound A2 showed a better activity than nalidixic acid and streptonium sulfate for Staphylococcus Aureus, Enterococcus Faecalis, Bacillus Subtilis and Klebsiella Pneumonia. The WH 104 compound was proved to be an inactive compound (pink colour for the main part of bacteria strain), but when WH 104 was added in small quantity to compound $\mathrm{A} 2$, the two combination gave remarkable results. They both have a lower minimal inhibitory
Epidermitis, Bacillus Cereus and Mycobacterium Smegmatis without talking about the bacteria strain for which A2 always showed a better activity. These concentrations became very small. The combination of the two compounds; A2 and $\mathrm{WH}$ 104; seemed to demonstrate a better activity beside the antibiotics and except for Klebsiella ocytoca.

\section{CONCLUSION}

One synthetic compound, pyrimido[1,2-a]benzimidazole with a dimethyled phenyl coupled with 1-ethylpropyl substituent on the pyrimidine ring ; was found to be active against Gram positive bacteria strain. The synergetic effects 
between A2 and WH 104 compounds showed remarkable results with minimal inhibitory concentrations which became lower than for two known antibiotics for 7 bacteria strain. These concentrations can decrease until $3 \mu \mathrm{g} / \mathrm{mL}$. On the other hand, two natural compounds have been studied and one of them called sigmoidin $\mathrm{B}$ is active against several bacteria strain with a concentration around $500 \mu \mathrm{g} / \mathrm{mL}$. However, the sigmoidin A also showed activity with lowest concentrations but it is just for 3 specific Gram-positive bacteria strain. Moreover, a novel type of anti-bacterial compounds has been discovered, which were active against all the 14 tested bacteria strain. It has been deducted that this activity was due to the presence of a triple bond associated with a ketone function.

\section{ACKNOWLEDGMENT}

I would like to thank and to show gratitude to the University of Johannesburg, my supervisor Dr Derek Ndinteh, Dr Djuidje Fotsing Martha from the applied chemistry department, Nicolette Niemann and Vuyo Mavumengwana (Department of biotechnology and food technology) for their availability and their help with microbiology. And lastly Professor Cecutti Christine, my tutor, for her advices concerning my professional project.

\section{REFERENCES}

[1] B Stuart, L. \& Marshall, B. Antibacterial resistance worldwide: causes, challenges and responses. Nat. Med. 10, S122 - S129 (2004). https://doi.org/10.1038/nm1145

[2] Krause, R. M. The origin of plagues: old and new. Science (80-. ). 257, 1073-1078 (1992). https://doi.org/10.1126/science.257.5073.1073

[3] Tenover, F. C. Mechanisms of antimicrobial resistance in bacteria. Am. J. Med. 119, S3-10; discussion S62-70 (2006).

[4] Walsh, C. T. Nature loves nitrogen heterocycles. Tetrahedron Lett. (2014).

[5] Kestwal, R. M., Konozy, E. H. E., Hsiao, C.-D., Roque-Barreira, M. C. \& Bhide, S. V. Characterization of alpha-mannosidase from Erythrina indica seeds and influence of endogenous lectin on its activity. Biochim. Biophys. Acta 1770, 24-8 (2007). https://doi.org/10.1016/j.bbagen.2006.07.008

[6] Dias, S. A., Neves, A. E. O., Ferraz, A. de B. F., Picada, J. N. \& Pereira, P. Neuropharmacological and genotoxic evaluation of ethanol extract from Erythrina falcata leaves, a plant used in Brazilian folk medicine. Rev. Bras. Farmacogn. 23, 335-341 (2013). https://doi.org/10.1590/S0102-695X2013005000015

[7] Gagdim, A. \& Musa, A. Isolation and identification of alkaloids of Erythrina abyssinica A Sudanese medicinal plant. Clin. Biochem. 44, $\underline{\mathrm{S}} 40(2011)$.

https://doi.org/10.1016/j.clinbiochem.2011.08.1053

[8] Cui, L., Ndinteh, D. T., Na, M., Thuong, P. T. \& Silike-muruumu, J. Isoprenylated Flavonoids from the Stem Bark of Erythrina abyssinica \#. 42, 1039-1042 (2007)

[9] Chen, D.-L. et al. Two new rotenoids from the roots of Millettia speciosa. Phytochem. Lett. 12, 196-199 (2015). https://doi.org/10.1016/j.phytol.2015.04.003

[10] Bosire, C. M., Deyou, T., Kabaru, J. M., Kimata, D. M. \& Yenesew, A. Larvicidal activities of the stem bark extract and rotenoids of Millettia usaramensis subspecies usaramensis on Aedes aegypti L. (Diptera: Culicidae). J. Asia. Pac. Entomol. 17, 531-535 (2014). https://doi.org/10.1016/j.aspen.2014.05.003

[11] Ingle, R. G. \& Magar, D. D. Heterocyclic Chemistry of Benzimidazoles and Potential Activities of Derivatives. Int. J. Drug Res. Tech. 1, 26-32 (2011).
[12] Yadav, G. \& Ganguly, S. Structure activity relationship (SAR) study of benzimidazole scaffold for different biological activities: A minireview. Eur. J. Med. Chem. 97, 419-443 (2014). https://doi.org/10.1016/j.ejmech.2014.11.053

[13] Ramprasad, J. et al. Synthesis and biological evaluation of new imidazo[2,1-b][1,3,4]thiadiazole-benzimidazole derivatives. Eur. J. Med. Chem. 95, 49-63 (2015).

https://doi.org/10.1016/j.ejmech.2015.03.024

[14] Kus, C., Ayhan-ktlctgil, G. \& Eke, B. C. Synthesis and Antioxidant Properties of Some Novel Benzimidazole Derivatives on Lipid Peroxidation in the Rat Liver OEt. 27, 156-163 (2004).

[15] Wang, Y.-T. et al. Synthesis, biological evaluation, and molecular docking studies of novel 1-benzene acyl-2-(1-methylindol-3-yl)benzimidazole derivatives as potential tubulin polymerization inhibitors. Eur. J. Med. Chem. 99, 125-137 (2015).

https://doi.org/10.1016/j.ejmech.2015.05.021

[16] Zawawi, N. K. N. A. et al. Novel 2,5-disubtituted-1,3,4-oxadiazoles with benzimidazole backbone: A new class of $\beta$-glucuronidase inhibitors and in silico studies. Bioorg. Med. Chem. 23, 3119-25 (2015).

https://doi.org/10.1016/j.bmc.2015.04.081

[17] Taha, M. et al. Synthesis of benzimidazole derivatives as potent $\beta$ glucuronidase inhibitors. Bioorg. Chem. 61, 36-44 (2015). https://doi.org/10.1016/j.bioorg.2015.05.010

[18] Shao, H. et al. Synthesis, structure-activity relationship and biological evaluation of 2,4,5-trisubstituted pyrimidine CDK inhibitors as potential anti-tumour agents. Eur. J. Med. Chem. 70, 447-55 (2013). https://doi.org/10.1016/j.ejmech.2013.08.052

[19] L. Cantas, S. Q. A. Shah, L. M. Cavaco, C. M. Manaia, F. Walsh, M. Popowska, H. Garelick, H. Bürgmann, and H. Sørum, "A brief multidisciplinary review on antimicrobial resistance in medicine and its linkage to the global environmental microbiota.," Front Microbiol, vol. 14, no. 9, pp. 96-96, 213AD.

[20] Y. Bansal and O. Silakari, "The therapeutic journey of benzimidazoles: a review.," Bioorg. Med. Chem., vol. 20, no. 21, pp. 6208-36, Nov. 2012.

https://doi.org/10.1016/j.bmc.2012.09.013

[21] P. Mehta, P. Davadra, N. Shah, and H. Joshi, "Synthesis and antimicrobial activity of some new imidazolinone derivatives containing benzimidazole," Int. Lett. Chem. Phys. Astron., vol. 10, pp. 74-80, 2014. https://doi.org/10.18052/www.scipress.com/ILCPA.29.74

[22] M. Othman, H. S. Loh, C. Wiart, T. J. Khoo, K. H. Lim, and K. N. Ting, "Optimal methods for evaluating antimicrobial activities from plant extracts," J. Microbiol. Methods, vol. 84, no. 2, pp. 161-166, 2011.

https://doi.org/10.1016/j.mimet.2010.11.008

[23] J. M. Andrews, "Determination of minimum inhibitory concentrations," J. Antimicrob. Chemother., vol. 48 Suppl 1, pp. 5-16, 2001.

https://doi.org/10.1093/jac/48.suppl_1.5

[24] A. Dalhoff, "In vitro activities of quinolones," Expert Opin. Investig. Drugs, vol. 8, pp. 123-137, 1999. https://doi.org/10.1517/13543784.8.2.123

[25] H. Wahe, P. F. Asobo, R. A. Cherkasov, A. E. Nkengfack, P. F. Folofoc, Z. T. Fomum, and D. Döpp, "Heterocycles of biological importance . Part 6 . The formation of novel biologically active pyrimido [ 1 , 2- a ] benzimid- azoles from electron deficient alkynes and 2-aminobenzimidazoles," Arkivoc, vol. 2003, no. xiv, pp. 170177, 2003.

[26] P. Forche Asobo, H. Wahe, J. T. Mbafor, A. E. Nkengfack, Z. T. Fomum, E. F. Sopbue, and D. Döpp, "Heterocycles of biological importance. Part 5. The formation of novel biologically active pyrimido[1,2-a]benzimidazoles from allenic nitriles and aminobenzimidazoles," J. Chem. Soc. Perkin Trans. 1, pp. 457-461, 2001.

https://doi.org/10.1039/b005511p 